\title{
The Significance of Coordination for Industrialised Building System (IBS) Precast Concrete in Construction Industry
}

\author{
Mohd Khairul Fitri Othman ${ }^{1,}$, , Wan Mohd Nurdden Wan Muhammad ${ }^{1}$, Nurulhudaya Abd \\ Hadi $^{1}$, and Mohd Azrai Azman ${ }^{1}$ \\ ${ }^{1}$ Faculty of Architecture, Planning and Surveying, Universiti Teknologi MARA, 94300 Kota \\ Samarahan, Sarawak
}

\begin{abstract}
IBS precast concrete is construction system which is meant to improve the conventional construction process. However IBS precast concrete projects are suffering from serious problems such as cost overrun, delays and less quality of the end product. The absence of coordination is perceived as the reason for this issue. The purpose of this paper is to review the significance of coordination for IBS precast concrete in the construction industry. It if found that the fragmentation which occurs in the construction industry requires continuity of coordination due to the construction activities are intertwined in nature. Coordination is designated to assist stakeholders in completing and complementing each other with the paramount focus of achieving the objective. Proper coordination is required in delivering the desired construction product at the ideal time, cost and quality. As for the findings, the significance of coordination for IBS precast concrete can be seen through the precast concrete construction phases which consist of planning; design; manufacturing; transportation and installation/construction. These phases are meant to complement construction process with the purpose to reduce issues of fragmentation and enhance IBS precast concrete project delivery.
\end{abstract}

\section{Introduction}

The construction industry is mostly characterized as a labour intensive industry, which comprises of several wet trade activities and hard labour conditions. Therefore, it is always facing with problems such as delay, cost overruns, low quality, poor safety records as well as environmental impacts [1]. Industrialisation has been viewed as one of a good method for providing solutions for problems mentioned above in construction [2]. It refers to the rationalisation of the construction process by promoting off-site manufacturing [3]. Industrialisation process comprises of investment of equipment, facilities and technology with the objective of maximising production output, minimising labour resource, and improving quality [4].

\footnotetext{
* Corresponding author: mohd_khairul135@sarawak.uitm.edu.my
} 
One of the principles of IBS in construction is precast concrete. Precast concrete is a construction system in which the concrete will be casted in the mold and then cured in a controlled environment, transported and assembled to produce the structure [5]. The components of precast concrete are produced under laboratory condition using high technology of machinery and computer aided system to meet high quality and durability of the product [6]. By these processes, the quality of precast concrete is known to be more reliable and accurate compared to in-situ concrete construction.

Precast concrete system offers several benefits such as reduce waste; encourage recycling construction waste; reduce construction site cost; improve site safety; enhancing quality under factory production; process standardization; shorten lead time; leading to environmental protection and sustainability; as well as improves construction performance [7]. In addition, precast concrete also contributes to sustainable practices by incorporating integrated design, using materials efficiently, reducing construction waste, site disturbance, and noise [3]. These arguments have clearly recognised IBS precast system as the way forward to improve the conventional concrete system in Malaysia.

The performance of the precast concrete system nevertheless is much dependent on comprehensive coordination between various relevant parties such as clients, architects, engineers, main contractors, subcontractors, suppliers and consultants, as well as the physical flow of materials, services and products. Any delay in delivering precast concrete components to a construction site will delay the construction processes thus increase the costs [8]. Coordination among project participants has been recognized as an important ingredient for the success of many projects [9]. Coordination is almost equivalent in meaning to 'control,' 'planning' or 'management,' but is more descriptive of the relating together of separate activities and their concerted direction towards a common purpose. It is supported by an argument that coordination as one of the principal functions of management, together with planning, organizing, directing and controlling. Moreover, it is also observed that active coordination could minimise, predict and remedy problems caused by design construct lead time, materials availability, manpower, and equipment availability.

\section{Coordination in construction industry}

The construction industry is critically being suffered from fragmentation issues. Clients, contractors, engineers, quantity surveyors are among the construction parties which directly contact with the construction activities and procedures. Nevertheless, each of the parties is not motivated to collaborate harmonically by self-voluntary [10]. The fragmentation which occurs in the construction industry requires continuity of coordination due to the construction activities are intertwined in nature. Otherwise, it will lead to poor performance of overall construction [11].

Coordination among stakeholders is claimed as a crucial element of the success of construction projects [9]. It is also one of the seven identified management processes besides forecasting, planning, organizing, motivating, controlling and communicating [9]. Coordination is also being defined as closely identical with the definition of control, planning or management. However, coordination is interpreted as more explanatory in collaborating different activities and their intensive focus in an achieving a common purpose [12]. Besides, coordination is also one of the three important functions in the building process together with design and construction [12]. These arguments on defining the coordination have deduced that coordination represents as an indispensable element in managing construction project holistically.

Coordination should be done continuously and it is required at all management levels. It shows that the management responsibility is essential in applying and following up the coordination activities. If any organisation in construction industry fails to coordinate its 
activities well continuously, the organisation might end up being unsuccessful for a long period [13]. This depiction shows that coordination is the quintessence of management and management functions cannot be achieved by the absence of proper coordination.

The importance of coordination in building construction is highly being recognised by construction players as a result of previous researcher's outcome. Coordination is designated to assist stakeholders in completing and complementing each other with the paramount focus of achieving the objective. The proper coordination activities as tools in managing coordination are required in supporting the desired meeting construction product and performance at the ideal time, cost and quality.

\section{Barriers for coordination}

Collaborating personnel from a different background is always deemed to contribute to fragmentation issues. The fragmented environment of the construction projects is one of the reasons of the poor performance. This is because most of the construction activities are interdependent and as a remedial action, coordination should take place in a continuous manner [14]. In describing the actual event, relationship based on prejudice between construction stakeholders is one of the industry predicament that influences the coordination process negatively [11]. It can be seen by many activities are performed in the project where if any of the parties come out with a different idea, the project stability is disturbed. The cooperation among the parties is expected to be insufficient and coordination should come into scene to mitigate the problem [10].

The source of the difficulty of construction projects management derives from the interdependent relationship between the parties. It is depicted with the lack of compromise between organisation and technical interdependence with the one who manage the activities [12]. In addition, lack of knowledge is also being argued as the obstacles of coordination. The ability of the parties will be in question while they are refuse to take part in the process. This circumstance is worsened by the communication issues which lead to the breakdown of information flow and failure of coordination process in project management [10].

The main impediment of the coordination application in the construction industry is mainly originated by the nature of being too dependent among project stakeholders and also among the process. Different 'language' and negative perception among the parties have led to communication problem which contributes to failure in achieving project objectives.

\section{Coordination phases in precast concrete construction}

In implementing a precast concrete system for construction, it is necessary to understand the coordination phases required during off-site and on-site operation to ensure successful implementation. In identifying the precast concrete coordination phases, the principles of the supply chain for precast concrete as being highlighted by Abedi et al. [5] are being utilised. This is due to the precast supply chain phases are intertwined with the coordination activities which being categorised as planning; design; manufacturing/production; transportation; and the installation/assembly and construction.

\subsection{Planning}

According to Kamar et al., [15] IBS project needs good planning in the aspect of manufacturing, transportation and erection on site. The decision of what component of 
precast concrete to be produced, what facilities needed to deliver the component and when the installation process will be carried out on the site should be taken into consideration. However, this planning decision should be performed in such a manner that the cost incurred is minimum. Another argument also supports that planning process involves obtaining and providing all documents and reports related to supply chain phase of precast construction [16], which including; design; manufacturing; cost analysis; transportation; installation and construction [17]. This is further supported by Yusof et al., [18] which mentioned that extensive planning and scheduling of activities in advance is crucial in achieving better project delivery and coordination of IBS project besides being recognised as one of the key success factors for IBS project which also apply to IBS precast concrete construction.

\subsection{Design}

The design of precast concrete component should be conducted thoroughly and carefully to avoid the design changes during construction. The design process should take into account the project's nature, regarding all its characteristics, surrounding environment, and ground conditions rather than only concerned with client need [19]. The most important process in design includes outline technical specification; design sketch; initial cost plan; provisional list of drawings required; and provisional list of annotations for drawings [20]. Kaner et al. [21] stated that all regulations, materials, drawing and appropriate building codes will be established. Furthermore, the quantities, cost estimations, time-scheduling will be prepared by designers and consultants [22]. Besides, the use of computer software such as BIM (Building Information Modelling) will help to enhance design analysis and components production. In the context of IBS precast concrete, standardisation towards process and design is an emphasis in utilising the concept of repetition [18]. These process and measures are important to be well-coordinated in order to convey accurate concept for the manufacturing process.

\subsection{Manufacturing}

Precast concrete components manufacturing process consist of several sections includes of raw materials selections, [23, 24], batching plant, casting and moulding zone, remoulding and finishing zone, packaging, transportation and the storage yard [25]. These processes manage to act as remedial action to diminish any non-value adding activities such as wastage of raw material; improper handling; long waiting time due to insufficient labour and raw material; double-handling or delivery due to unsatisfied quality or specifications should be avoided [23]. Peng [23], mentioned that manufacturing activities in precast concrete factories could be identified into four phases, includes of site layout management, delivery management of raw materials, production management, and stock management.

\subsection{Transportation}

Transportation issues are one of the challenges in managing IBS construction. The issues normally associated with size and weight limitations, route restrictions, permitting and the availability of lifting equipment [26]. Transportation management should concentrate on the construction schedule, site layout, cost of plant and the design of plan [27]. Transportation consideration will influence the design of precast components such as size and weight. Based on the study made by Warszawski [28], the length of a volumetric unit should not exceed 12 meter which is the normal vehicle length. The precast components' height, when loaded on the trailer, should not exceed a height limitation of highway ranging 
from 4.8 to 5.1 meter. The weight of precast concrete component should not exceed 7 tonnes to ensure that a crane can easily erect and transport the material on site [29]. Furthermore, the suitable distance of fabrication plant from development area should be from 50 to $100 \mathrm{~km}$, based on the study made by Azman et al., [29]. These considerations are established with the purpose to promote efficient and effective transportation with proper coordination in transferring the components from fabrication plant to site.

\subsection{Installation and construction}

The reliability of precast concrete construction also depends on the expertise level of a labourer in carrying out the installation task. A thorough supervision, especially in jointing, should be executed to prevent a problem such as water seepage through precast concrete connection [30]. The installation drawings, time-scheduling and instructions which has been produced during a planning phase should be followed accordingly [31]. Furthermore, the delivery process of the precast concrete component to the site should have a continuity and just in time to avoid delay in the installation process and buffer stocks kept on site. As for handling purposes, a tower crane and mobile crane will be used for unloading and placing the component on site as well as for installation [30]. The loading capacity of hoists and cranes for installation of precast concrete components need to be considered based on their weight and size $[32,30]$. High accuracy and efficiency when handling IBS components are essential by properly coordinate them during installation and storage [33] with the purpose to avoid a serious problems such as delay and wastage.

\section{Discussion}

Coordination plays an important function having a considerable effect on the outcome of a construction project. This paper highlighted five phases of coordination based on the critical review of previous researchers regarding construction coordination and precast concrete which includes of planning, design, manufacturing, transportation and installation/ construction.

It is argued that planning phase is the important process where all the documents for all coordination phases would be provided. A variety of reports such as design component, production resources, cost analysis component, installation schedules, bill of quantities, shop drawings and construction drawings are among other reports that will be provided in planning phase. All of these reports are needed to be well-coordinated in order to avoid fragmentation issues in the production of precast concrete.

Meanwhile, design phase also plays a vital process throughout the precast concrete production. In the design process, the designers together with manufacturer and contractor should be involved to avoid constructability issues in future such as delay, late of supply, etc. The technical specification and regulations, types of materials, drawings and the appropriate building codes will be developed. All the drawing produced such as M\&E, $\mathrm{C} \& \mathrm{~S}$ and architectural drawing should be aligned to avoid disparity. The detailing of structural including joints and connections should also be put into consideration in the design of precast concrete components. All of these processes are required to reduce the errors and discrepancy throughout the precast concrete production, thereby mitigating the delay and incurred cost of rework.

As for manufacturing phase, the precast concrete components are carried out in a factory and systematically done using machine, formwork and other forms of mechanical 
equipment. The manufacturing process will be categorized into several significant sections consisting of the selection of raw materials, batching plant, moulding zone, finishing zone, packaging, and the storage yard. Besides, crew allocation in every section should be optimised in order to minimise idle times caused by sharing operatives. All of these activities which involved material and human resource should be coordinated wisely to minimise resource wastage and reduce defects and errors in precast concrete production.

The transportation and delivery of precast concrete component should be planned according to the appropriate delivery schedule, quantities, arrival orders, unloading sequences and erection sequence to minimise unnecessary site storage and handling. The transportation of large panels or components is also subject to the restriction of traffic congestion and regulation of the road and transportation authority. The limitations must be taken into consideration when designing and manufacturing a precast concrete system. Where possible, the precast concrete components should be arranged and transported in a manner which they can be easy lifted directly from the lorry for the erection or storage. All these considerations are needed to ensure the precast concrete component can be transported and delivered in efficiently and effectively.

In the installation/construction phase, all the precast components will be installed/assembled based on the appropriate documents which are produced in the planning phase. The installation process should be conducted by the skilled labourers who have expertise in the precast concrete components to avoid poor performance on the structures such as crack, moisture penetration, etc. It is also argued that good integration between all construction members is essential to the successful precast concrete construction. A suitable plant with appropriate loading capacity should be available to use for the site storage and installation of precast components. All these considerations should be well-coordinated to avoid improper assembly of the components thus reduce the defects of the precast concrete construction.

By scrutinising these coordination phases for precast concrete system, it highlights on the apparent gap between the precast concrete system with the significance of associating coordination alongside with the system activities. The coordination activities play important roles in addressing the shortcoming of precast concrete system operation. They also raise up the importance to understand the characteristics of precast concrete system which normally have a relation to the impediment of successful precast concrete system operation. Hence, it is argued that coordination is capable of mediating the deficiencies of precast concrete system.

\section{Conclusion}

IBS is widely recognised by construction players in Malaysia since its first implementation in the 1960s. Nevertheless, most of the construction project is still carried out in conventional ways due to the absence of coordination in the overall construction process. Coordination is perceived as a paramount element in precast concrete construction. Lack of coordination between design and construction will give adverse effects on construction such as delay and cost overrun. The significance of coordination for IBS precast concrete can be seen through the precast concrete construction phases consist of planning; design; manufacturing; transportation; and installation/construction. These phases are meant to harmonise construction process with the purpose to reduce issues of fragmentation and enhance IBS precast concrete project delivery. Further research is required to identify and verify important coordination activities through precast concrete construction phases and their relationship with precast concrete characteristics. 
These researchers would like to express gratitude for the financial support from Kementerian Pendidikan Malaysia (KPM) under the purview of Research Acculturation Grant Scheme (RAGS) 600-RMI/RAGS 5/3 (237/2014) and Research Management Institute (RMI) Universiti Teknologi MARA (UiTM).

\section{References}

[1] A.P.C. Chan and T.Y.F. Ma, Materials wastage on commercial projects - contractor's view, Proc. of the Sixth East Asia-Pacific Conf. on Structure Engineering and Construction, Taipei, Taiwan, (1998)

[2] L. Koskela, Application of new production theory in construction, CIFE Technical Report No. 72, Center for Integrated Facility Engineering, Stanford University, Finland, (1992)

[3] G. Polat, Precast concrete systems in developing vs industrialized countries, J. Civ. Eng. Manag., 16(1), 85-94, (2010)

[4] W.A. Thanoon, L.W. Peng, M.R. . Kadir, M.S. Jaafar and M.S. Salit, The essential characteristics of industrialised building system, Int. Conf. Ind. Build. Syst, Kuala Lumpur, Malaysia, 1999, 10-11, (2003)

[5] M. Abedi, N.M. Rawai, M.S. Fathi and A.K. Mirasa, Cloud computing as a construction collaboration tool for precast supply chain management, J. Teknol., 70(7), 1-7, (2014)

[6] A. Neville, Some aspects of sustainability, PCI J., 50(5), 2-5, (2005)

[7] Y. Chen, G.E. Okudan and D.R. Riley, Sustainable performance criteria for construction method selection in concrete buildings, Autom. Constr., 19(2), 235-244, (2010)

[8] A.F. Al-Bazi, N. Dawood and J.T. Dean, Improving performance and the reliability of off-site pre-cast concrete production operations using simulation optimisation, J. Inf. Technol. Constr., 15, 335-356, (2010)

[9] K.N. Jha and K.C. Iyer, Critical determinants of project coordination, Int. J. Proj. Manag., 24, (4), 314-322, (2006)

[10] W.S. Alaloul, M.S. Liew and N.A.W.A. Zawawi, The characteristics of coordination process in construction projects, Proc. of the Int. Symposium on Technology Management and Emerging Technologies, IEEE, 159-164, (2015)

[11]K.H. Tey, M.Y. Aminah, I. Syuhaida and F. W. Lee, A conceptual study of key barriers in construction project coordination, J. Organ. Manag. Stud., 2012, 333-346, (2012)

[12] G. Higgin and N. Jessop, Communications in the building industry: The report of a pilot study, Tavistock Publications, London, United Kingdom, (1965)

[13]M.J. Meixell, M. Nunez and A. Talalayevsky, Activity structures in a project-based environment: A coordination theory perspective, Eng. Manag. IEEE Trans., 53, 285296, (2006)

[14]Ö. Wikforss and A. Löfgren, Rethinking communication in construction, Proc. of the 4th Nordic Conf. on Construction Economics and Organisation, 337-344, (2007)

[15]K.A.M. Kamar, Z.A. Hamid, M. Zura, M. Zain, A. Hazim, A. Rahim, M.K. Ghani, M. Nor, A. Azman, T.A. Majid, M. Sanusi, S. Ahamad and M.N. Azman, Drivers and barriers of industrialised building system (IBS) roadmaps in Malaysia, Malaysian Constr. Res. J., 9(1), 1985-3807, (2012)

[16]W.T. Chan and H. Hu, Constraint programming approach to precast production scheduling, J. Constr. Eng. Manag., 128(6), 513-521, (2002) 
[17]E. Dassori and M. Frasani, Support system for project management and production of concrete precast elements, Int. Conf. on Advances in Building Technology, 1689-1696, (2002)

[18] M.R. Yusof, A.H. Nawawi, M.F. Mohammad and M.F. Musa, Key success factors in IBS project management, Colloquium on Humanities, Science and Engineering, IEEE, 210-215, (2015)

[19]N.B. Kiong and Z.A. Akasah, Maintenance factor for precast concrete in IBS: A review, 2011 Natl. Postgrad. Conf. - Energy Sustain. Explor. Innov. Minds, NPC 2011, Kuala Lumpur, Malaysia, (2011)

[20] S.V.N. Biscaya, Coordination and management of information for construction design projects: A framework for Portugal, PhD Thesis, University of Salford, United Kingdom, (2012)

[21]I. Kaner, R. Sacks, W. Kassian and T. Quitt, Case studies of BIM adoption for precast concrete design by mid-sized structural engineering firms, Electron. J. Inf. Technol. Constr., 13(2007), 303-323, (2008)

[22] V. Mlinarić and Z. Sigmund, Problems in large scale precast construction projects, $C I B$ Jt. Int. Symp. 2009 Constr. Facing Worldw. Challenges, Dubrovnik, Croatia, 182-188, (2009)

[23] W. Peng and L.S. Pheng, Lean production, value chain and sustainability in precast concrete factory - a case study in Singapore, Lean Constr. J., 2011, 19-36, (2010)

[24]P.W. and S.P. Low, Lean management and low carbon emissions in precast concrete Factories in Singapore, J. Archit. Eng., 18, 176-186, (2011)

[25] S. Senaratne and S. Ekanayake, Evaluation of application of lean principles to precast concrete bridge beam production process, J. Archit. Eng., 18(2), 94-106, (2012)

[26] C.T. Haas and W.R. Fagerlund, Preliminary research on prefabrication, pre-assembly, modularization and off-site fabrication in construction, PPMOF Technical Reprot No. 171, The Construction Industry Institute, Austin, Texas, (2002)

[27]I.L. Jabar, F. Ismail and A.A. Mustafa, Issues in managing construction phase of IBS Projects, Procedia - Soc. Behav. Sci., 101, 81-89, (2013)

[28]A. Warszawski, Industrialised and automated building systems, E \& FN Spon, London, United Kingdom, (1999)

[29] M.N.A. Azman, M.S.S. Ahamad, T.A. Majid and M.N.S.A. Shah, A study of precast concrete in Malaysia, Concrete, 46(10), 50-52, (2012)

[30] Y.W. Cheong, H.P. Kwan and A. D. Hariyanto, Quality control in precast production: a case study on tunnel segment manufacture, Dimensi Teknik Arsitektur, 33(1),153$164,(2005)$

[31]A. Rönneblad and T. Olofsson, Application of IFC in design and production of precast concrete constructions, J. Inf. Technol. Constr. (ITcon), 8, 167-179, (2003)

[32]L.S. Pheng and C.J. Chuan, Just-in-time management in precast concrete construction: a survey of the readiness of main contractors in Singapore, Integr. Manuf. Syst., 12, 416-429, (2001)

[33] W.M.N.W. Muhammad, M.A. Azman, M.K.F. Othman, N.A. Hadi, S.N.S. Sahimi, and M.F. Mohammad, The insight of industrialised building system (IBS) by Bumiputera construction players, The 3rd Int. Conf. on Civil and Environmental Engineering for Sustainability Malacca, Malaysia, (2016) 